\title{
The analysis of disruption management due to COVID-19 using business continuity management and house of risk on maritime operations
}

\section{Research Article}

Keywords:

Posted Date: April 1st, 2021

DOl: https://doi.org/10.21203/rs.3.rs-111840/v2

License: (c) (i) This work is licensed under a Creative Commons Attribution 4.0 International License.

Read Full License 


\section{Abstract}

The authors have requested that this preprint be withdrawn due to erroneous posting.

\section{Full Text}

The authors have withdrawn this preprint from Research Square. 